\title{
Distinctive Anatomical Features of the Branchial Basket in fOUR CaRapidae SPECIES (OPHIDIIFORMI, ParacanthopterygiI)
}

\author{
Pierre Vandewalle ${ }^{1}$, Eric Parmentier ${ }^{1}$, Mathieu Poulicek ${ }^{2}$, \\ Jean-Claude Bussers ${ }^{2}$ and Michel Chardon ${ }^{1}$
}

\author{
${ }^{1}$ Lab. Functional and Evolutive Morphology, Inst. Zoology, Univ. Liège, Liège, Belgium \\ ${ }^{2}$ Lab. Marine Ecology, Inst. Zoology, Univ. Liège, Liège, Belgium
}

\begin{abstract}
The present study focuses on the branchial basket in four Carapidae species: Carapus acus, Encheliophis boraborensis, Encheliophis homei and Encheliophis gracilis. The aim is to highlight the skeletal and muscular features of the branchial basket, especially those that are believed to be related to their way of life and/or to be linked to the presence of primary sound-producing muscles.

The space occupied by the primary sound-producing muscles between the neurocranium and the branchial basket gives rise to distinctive skeletal and muscular features. They prevent the 1st pharyngobranchials from becoming attached to the neurocranium in the normal way. These do not seem to play any role in the suspension of the upper pharyngeal jaws, as it is usually the case in teleosteans. The 1st epibranchials are separated from the 2nd pharyngobranchials. Ossified interarcual elements jointed to the 2 nd pharyngobranchials and 1 st epibranchials are found in the position usually occupied by the latter. The presence of primary sound-producing muscles gives rise to the need for the reorganisation of the musculature which is seen in particular with regards to the levatores branchiales. These are not found on the neurocranium but on the hyomandibular.

The general skeletal and muscular data and the observations of the stomach contents suggest that the action of the branchial basket is restricted to carrying food in Carapus acus, Encheliophis boraborensis and Encheliophis homei, whereas it could also play a role in the work of cutting up soft food in Encheliophis gracilis.
\end{abstract}

KEYWORDS: Carapidae, Carapus, Encheliophis, pharyngeal jaw, sound-producing muscle, branchial muscle.

\section{INTRODUCTION}

The Carapidae (Ophidiiformi) are fish whose ethology has intrigued scientists for many years (Emery, 1880; Hipeau-Jacquotte, 1967; Trott, 1970; Gustato, 1976; Meyer-Rochow, 1977; Smith et al., 1981; Govoni et al., 1984). With the exception of few pelagic

Address correspondence to: Prof. Pierre Vandewalle, Institut de Zoologie, Laboratoire de Morphologie fonctionnelle et évolutive, Université de Liège, Quai Van Beneden, 22, B-4020 Liège, Belgium. E-mail: P.Vandewalle@ulg.ac.be species, the majority of the Carapidae display amazing behaviour: they are able to enter, leave and remain in an echinoderm host in particular. These Carapidae are commensals or parasites.

Trott (1970) and Markle and Olney (1990) highlighted a series of anatomical features in Carapidae that they believe are related to the gradual transition from a pelagic way of life to a parasitic style, including a benthic and then a commensal transitional stage. This evolution in behaviour is believed to be accompanied by morphological changes such as the loss of scales, pectoral fins, pelvic fins, the caudal fin, etc. 
Emery (1880), Bougis and Ruivo (1952), Courtenay and McKittrick (1970) and Courtenay (1971) observed the presence of two pairs of so-called "soundproducing" muscles in several species of Ophidae, Brotulidae and Carapidae. In the latter, the "primary" sound-producing muscles are found at the front in the orbital roof, run ventrally alongside the skull and are fixed at the back on the anterior upper part of the swim bladder. "Secondary" sound-producing muscles run from the occipital region to the first pair of ribs. The sound-producing muscles are thought to be derived from the modifications of the epaxial musculature and of the Baudelot ligament (Courtenay \& McKittrick, 1970; Courtenay, 1971; Howes, 1992). They are believed to play a role in the emission of sounds or vibrations like certain muscles observed in the Ariidae, Pimelodidae and Holocentridae (Tavolga, 1962; Winn \& Marshall, 1963; Courtenay \& McKittrick, 1970; Courtenay, 1971; Demski et al., 1973; Markle \& Olney, 1990).

This study aims at highlighting the skeletal and muscular characteristics of the branchial basket in carapid fish, especially those that could be related to their way of life and/or linked to the presence of the primary sound-producing muscles.

This paper considers four easily obtainable Carapidae species. In accordance with the systematic denomination given by Markle and Olney (1990), these are Carapus acus (Brunnich, 1768), Encheliophis boraborensis (Kaup, 1856) (formerly Carapus parvipinnis), Encheliophis homei (Richardson, 1844) (formerly Carapus homei) and Encheliophis gracilis (Bleeker, 1856). The four species are carnivorous. The first three are considered to be commensals (Arnold, 1953; Smith, 1964; Trott, 1970; Van Den Spiegel \& Jangoux, 1989), while the fourth is considered to be a parasite (Strasburg, 1961; Smith, 1964; Trott, 1970; Van Den Spiegel \& Jangoux, 1989).

The nomenclature used to designate parts of the skeleton and musculature of the branchial basket is based on the works of Nelson (1967), Winterbottom (1974), and Liem and Greenwood (1981).

\section{MATERIALS AND METHODS}

Encheliophis boraborensis, Encheliophis homei, and Encheliophis gracilis specimens were collected in Hansa bay (Laing Island biological station, Bismarck sea) on the north coast of Papua New Guinea). They were found inside specimens of Bohadschia argus (a holothurian). The specimens of Carapus acus were taken from the Mediterranean sea (S.T.A.R.E.S.O. station, Calvi, Corsica). They were found in Holothuria forskälli. The carapids were preserved in formalin (5\%) or frozen at $-20^{\circ} \mathrm{C} .8$ E. boraborensis (TL: between 13 and $28 \mathrm{~cm}$ ), 9 E. homei (TL: between 10 and $17 \mathrm{~cm}$ ), 6 C. acus (TL: between 7 and $15 \mathrm{~cm}$ ) and $5 E$. gracilis (TL: between 16 and $24 \mathrm{~cm}$ ) were examined. Three specimens of E. boraborensis, E. homei and $C$. acus, and two specimens of E. gracilis were stained with Alizarin and/or Alcian blue using the Taylor and Van Dijk (1985) method so as to reveal the skeletal structures. All the fish were dissected and examined with a Wild M10 binocular together with a camera lucida.

Pharyngeal teeth of the four species were dehydrated and underwent metallization by Au-Pd pulverization (Balzers SCD-30). Photographs were taken with a scanning electron microscope (JEOL, JSM 840) under a acceleration voltage of $19 \mathrm{KV}$.

\section{RESULTS}

\section{Skeleton}

The first three branchial arches are each composed of a basibranchial, two hypobranchials, two ceratobranchials, two epibranchials and two pharyngobranchials. However, the first arch is particular: (1) it is not connected to 2nd pharyngobranchials; (2) it has two supernumerary bones called "interarcual element" (Allis, 1915). For each half branchial basket, the latter is articulated on the one side with the uncinate process of the 1st epibranchial and on the other side with the posterior end of the 2 nd pharyngobranchial (Fig. 1); (3) it is extended dorsally by reduced, cartilaginous pharyngobranchials buried in the conjunctive tissue that are not directly connected to the neurocranium; (4) in E. boraborensis, C. acus and E. homei, it has three particularly developed gill rakers on the ceratobranchials (Fig. 2). The fourth arch does not have any hypobranchials and has a cartilaginous basibranchial. The fifth arch simply comprises toothed ceratobranchials that form the lower pharyngeal jaws (LPJ) (Fig. 3).

The disposition and the form of the fifth ceratobranchials differ between the four species examined. Generally speaking, in E. boraborensis, C. acus and E. homei, the 5th ceratobranchials are robust, their 


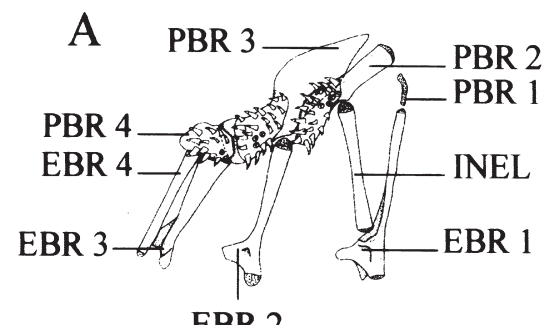

EBR 2

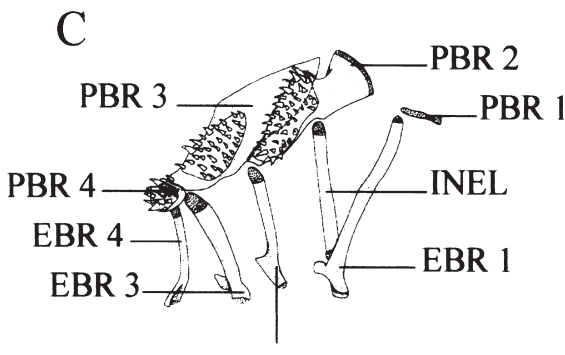

EBR 2
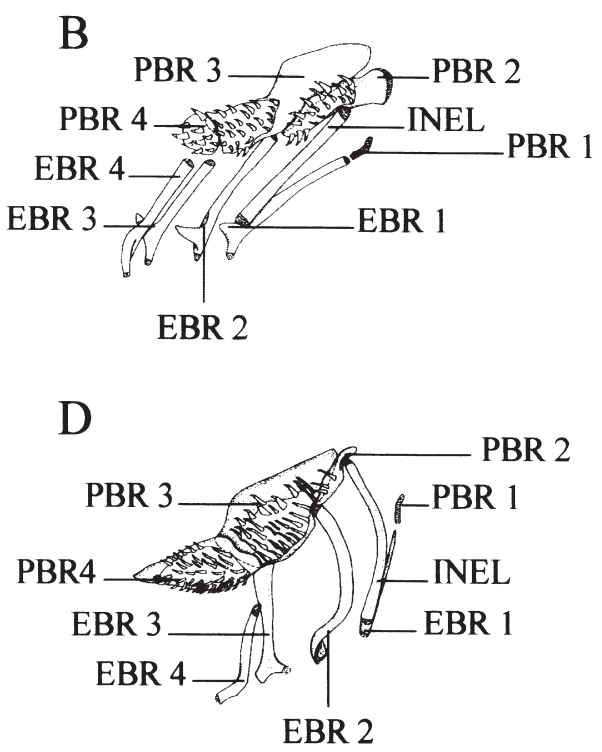

Fig. 1. Ventral view of the half left upper pharyngeal jaw in A: Encheliophis boraborensis, B: Encheliophis homei, C: Carapus acus and D: Encheliophis gracilis.

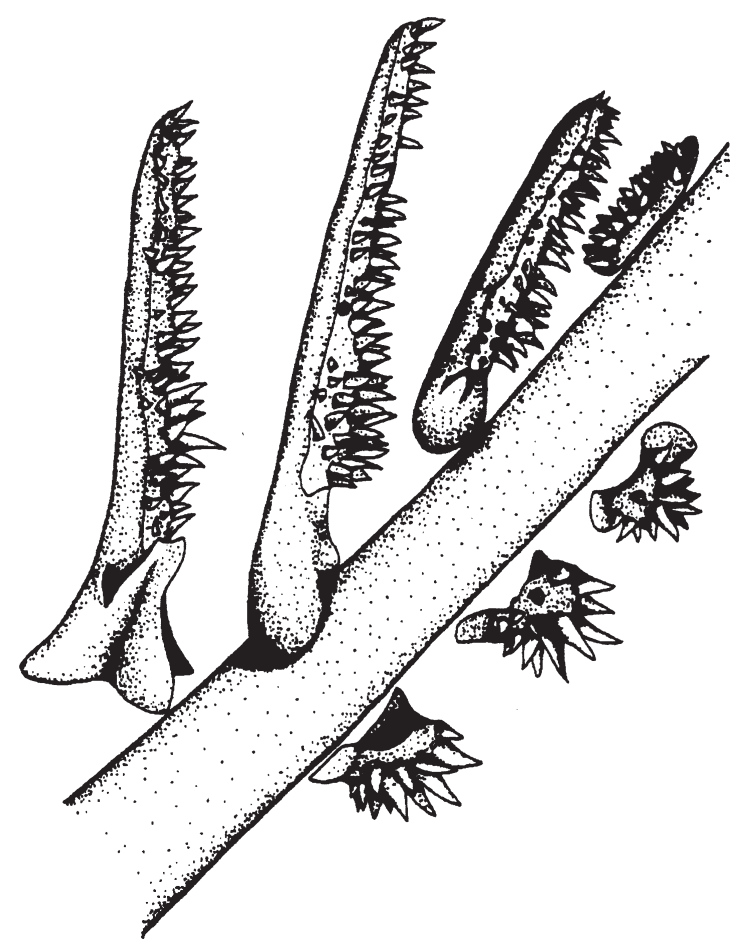

Fig. 2. Lateral view of some gill rakers with the three particularly developed on the 1st ceratobranchial in Encheliophis boraborensis. upper surface has big teeth on the inner side and small teeth on the outer side (Fig. 3). These teeth end in a conical dome and are oriented towards the back of the buccopharyngyal cavity (Fig. 4.2). In E. gracilis, the 5 th ceratobranchials are flattened and separated from each other. From a dorsal view, they slope laterally and bear only cardiform teeth (so called by Markle \& Olney, 1990) on their inner upper surfaces (Fig. 4). These teeth also end with a small cone and are organised in several perfectly aligned rows (Figs 3, 4.2D). In the four species, a membrane joins the right and left 5 th ceratobranchials.

In the four species, the 2nd, 3rd and 4th pharyngobranchials form the upper pharyngeal jaws (UPJ) (Fig. 1). In all cases, the 3rd pharyngobranchials are surmounted in front by the 2nd pharyngobranchials and at the back by the 4 th pharyngobranchials. C. acus has the most developed 2nd pharyngobranchials and 1 st epibranchials. These elements are smaller in $E$. boraborensis and E. homei, and E. gracilis has reduced 2nd pharyngobranchials and very fine 1st epibranchials. However, in the latter species, the 4th pharyngobranchials are the most important (Fig. 4) compared with other species.

The UPJ contain conical teeth surmounted by a small sharp cone and pointing to the rear and the centre of the branchial cavity (Fig. 4.1). Teeth are more numerous and more tapered in E. gracilis (Figs. 3, 4). 

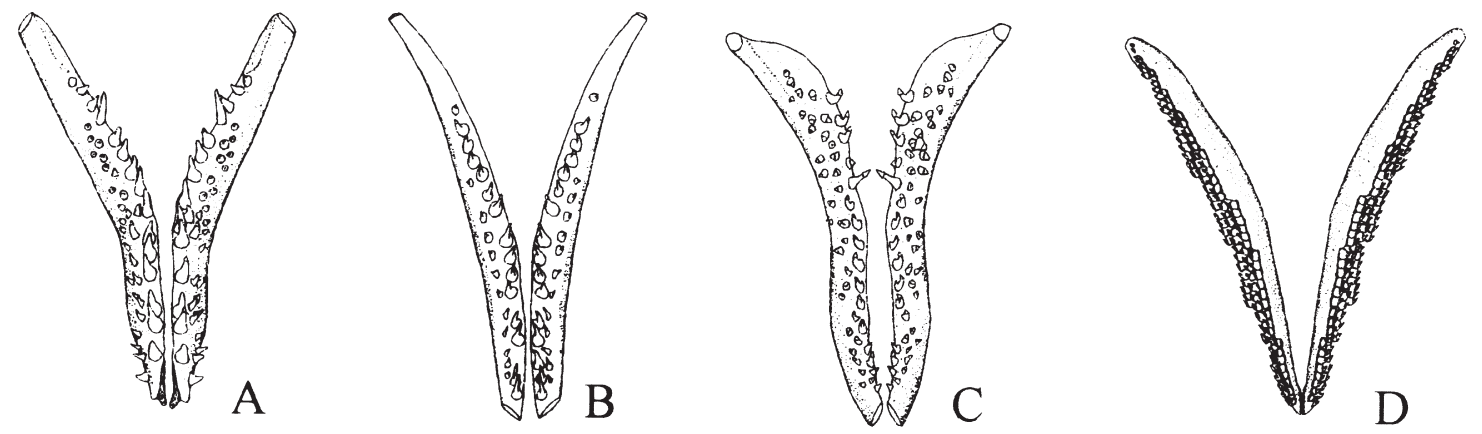

Fig. 3. Dorsal view of the lower pharyngeal jaws in A: Encheliophis boraborensis, B: Encheliophis homei, C: Carapus acus et D: Encheliophis gracilis.

TABLE 1. Enumeration of the branchial basket muscles and of their insertions. (*) indicates that they are particularities in E. gracilis.

\begin{tabular}{|c|c|c|}
\hline Muscle & Origin & Insertion \\
\hline LEXT 1 to 4 & upper inner face of the hyomandibular & EBR 1 to 4 \\
\hline LINT $2 / 3$ and 4 & upper inner face of the hyomandibular & PBR $2 / 3$ and 4 \\
\hline LINT $3(*)$ & upper inner face of the hyomandibular and prootic & PBR 3 \\
\hline \multicolumn{3}{|l|}{ obliquus } \\
\hline OBLDO 1 & PBR 2 & EBR 1 \\
\hline OBLDO 2 & PBR 2 & EBR 2 \\
\hline OBLDO $3 \mathrm{~s}$ & PBR 2 and 3 & EBR 3 \\
\hline OBLDO 3p & PBR 2 & EBR 3 \\
\hline OBLDO 4 & PBR 4 & EBR 4 \\
\hline OBLV 1 & HBR 1 & CBR 1 \\
\hline OBLV 2 & HBR 2 & CBR 2 \\
\hline OBLV 3 & HBR 3 & CBR 3 \\
\hline OBLPO & PBR 4 & CBR 5 \\
\hline OBLPO $(*)$ & EBR 4 & CBR 5 \\
\hline \multicolumn{3}{|l|}{ transversus } \\
\hline TRD 1 & PBR 2 & median aponeurosis \\
\hline TRD 2 & EBR 2 & median aponeurosis \\
\hline TRD 3 & EBR 3 & median aponeurosis \\
\hline TRV 1 & (left) CBR 4 & (right) CBR 4 \\
\hline TRV 2 & (left) CBR 5 & (right) CBR 5 \\
\hline \multicolumn{3}{|l|}{ rectus } \\
\hline RECTV & HBR 3 & CBR 4 \\
\hline RECTC & URH & CBR 5 \\
\hline dorsalis & & \\
\hline REDO 1 & PBR 2 & INEL \\
\hline REDO 2 & INEL & EBR 2 \\
\hline REDO 3 & EBR 2 & EBR 3 \\
\hline REDO 4 & EBR 3 & EBR 4 \\
\hline \multicolumn{3}{|l|}{ pharyngocleithralis } \\
\hline PHCE & SCAP & CBR 5 \\
\hline PHCI & SCAP & CBR 5 \\
\hline RD vertebras 2 and 3 & PBR 3 & \\
\hline adductor branchialis 5 & EBR 4 & CBR 5 \\
\hline adductor branchialis 5 (*) & EBR 3 and 4 & CBR 5 \\
\hline
\end{tabular}

Fig. 4. View of the teeth of the upper pharyngeal jaws (1) and of the lower pharyngeal jaws (2) in A: Encheliophis boraborensis, B: Encheliophis homei, C: Carapus acus and D: Encheliophis gracilis. 

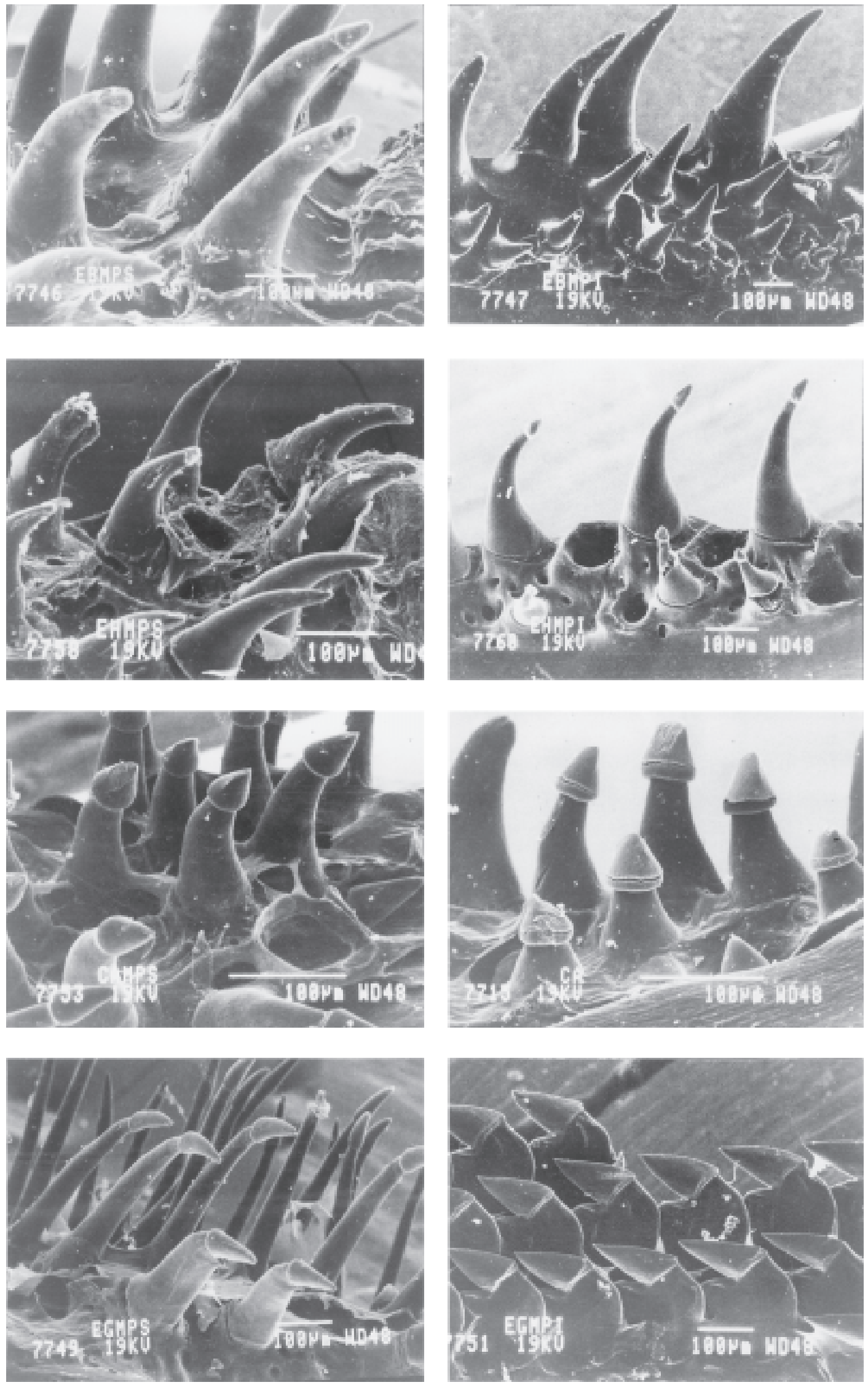


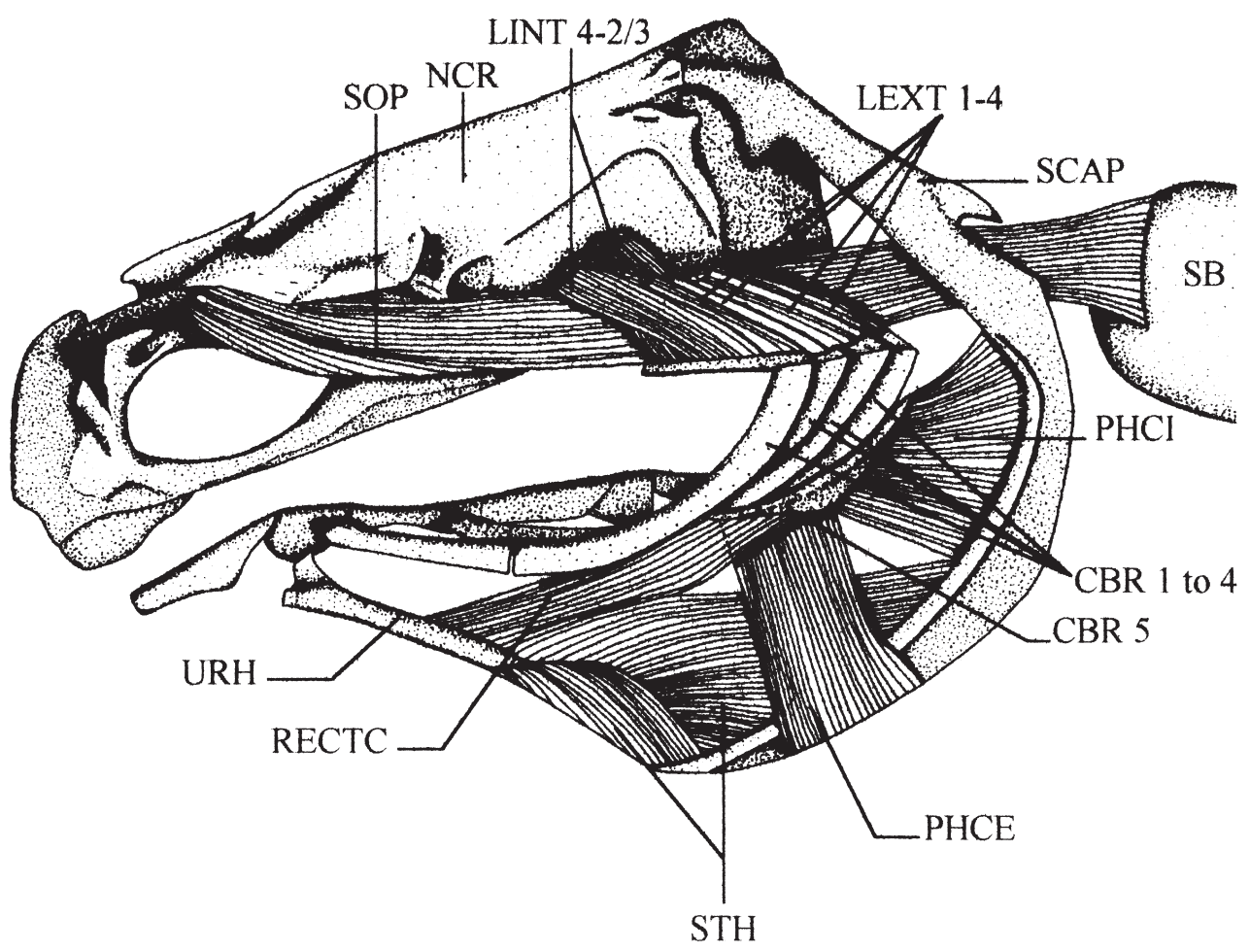

Fig. 5. Lateral view of the neurocranium, the branchial basket musculature and the right primary sound-producing muscle in Encheliophis boraborensis. Teeth and gill rakers are not shown.

E. boraborensis and C. acus also have teeth on the 3rd basibranchial and on the 3rd hypobranchials, whereas $E$. homei only had teeth on the 3rd basibranchial. These teeth are missing in E. gracilis.

\section{Musculature}

Each of the four species of Carapidae observed has two primary sound-producing muscles (Fig. 5). Each muscle has its origin on the swim bladder and its insertion on its respective frontal.

The branchial basket muscles and their insertions are listed in Table 1.

Despite the information given in Table 1 and in the figure (Figs. 5, 6, 7, 8, 9), a few anatomical details should be specified. The 4th levator internus slopes steeply and its origin is on the inner surface of the hyomandibular in front of the $2 \mathrm{nd} / 3 \mathrm{rd}$ levator internus. These muscles are therefore crossed (Figs. 5, 10). The levatores externi muscles are found further to the back and lower down than the levatores interni on the inner surface of the hyomandibular. They run in rostrodorsal direction. Therefore all the levatores may also be considered to be UPJ protractors.

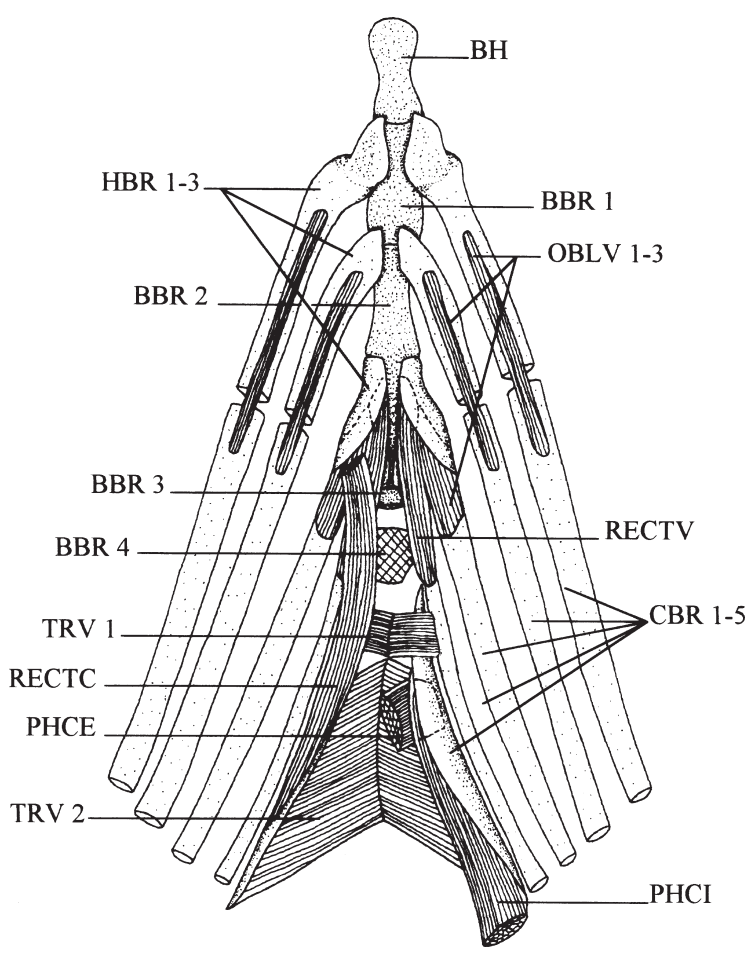

Fig. 6. Ventral view of the branchial basket ventral musculature in Encheliophis boraborensis. 
A

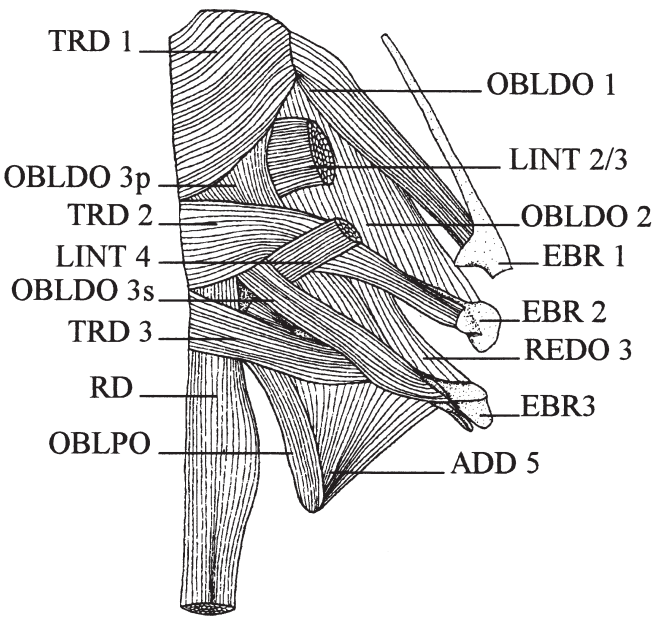

B

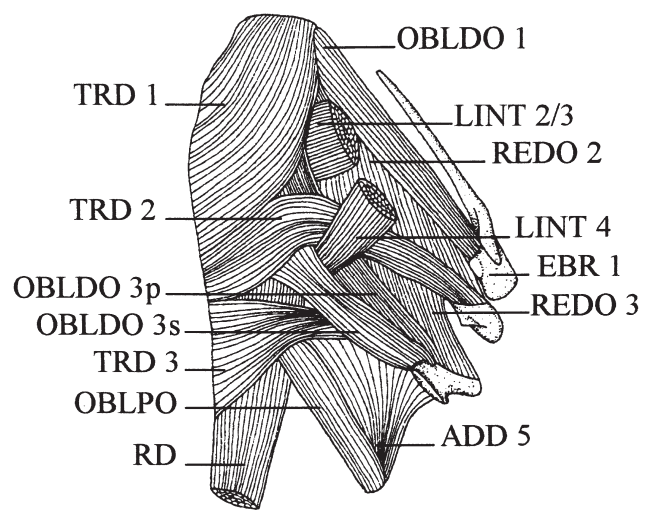

C

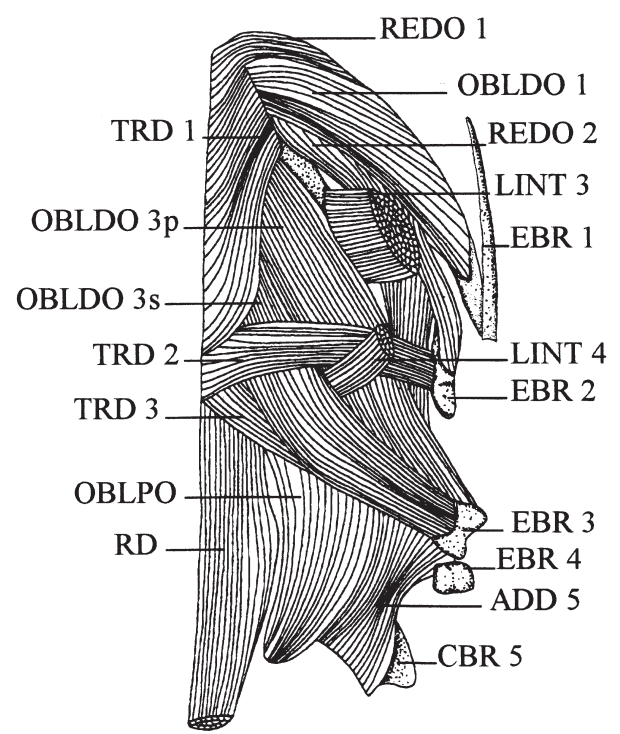

Fig. 7. Dorsal view of the half right branchial basket dorsal musculature in A: Encheliophis boraborensis, B: Encheliophis homei, C: Encheliophis gracilis.
A

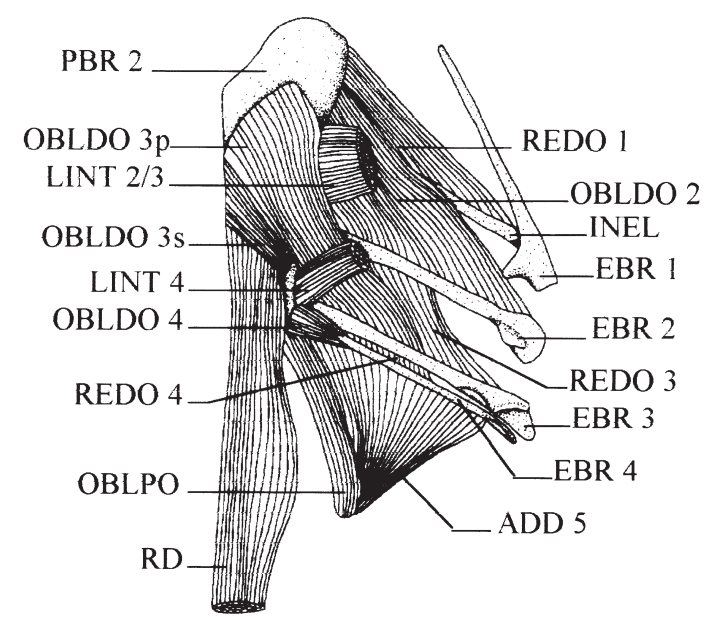

B

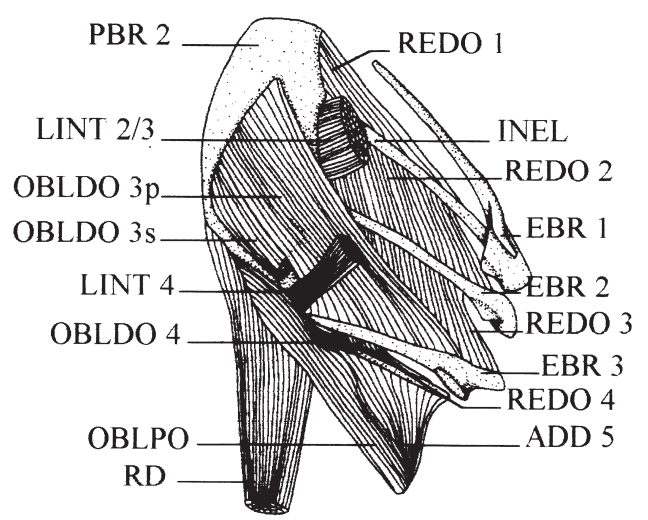

C

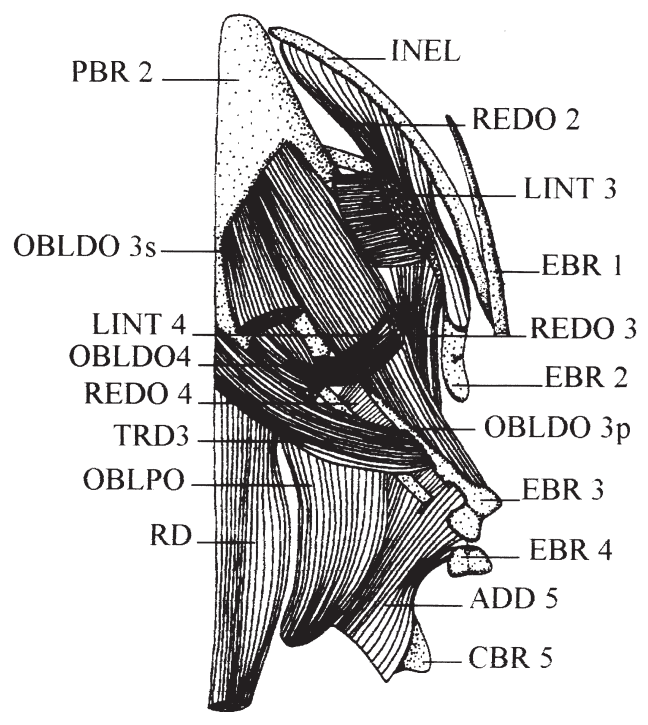

Fig. 8. Dorsal view of the half right branchial basket dorsal musculature when the transversus dorsalis are removed in A: Encheliophis boraborensis, B: Encheliophis homei, C: Encheliophis gracilis. 

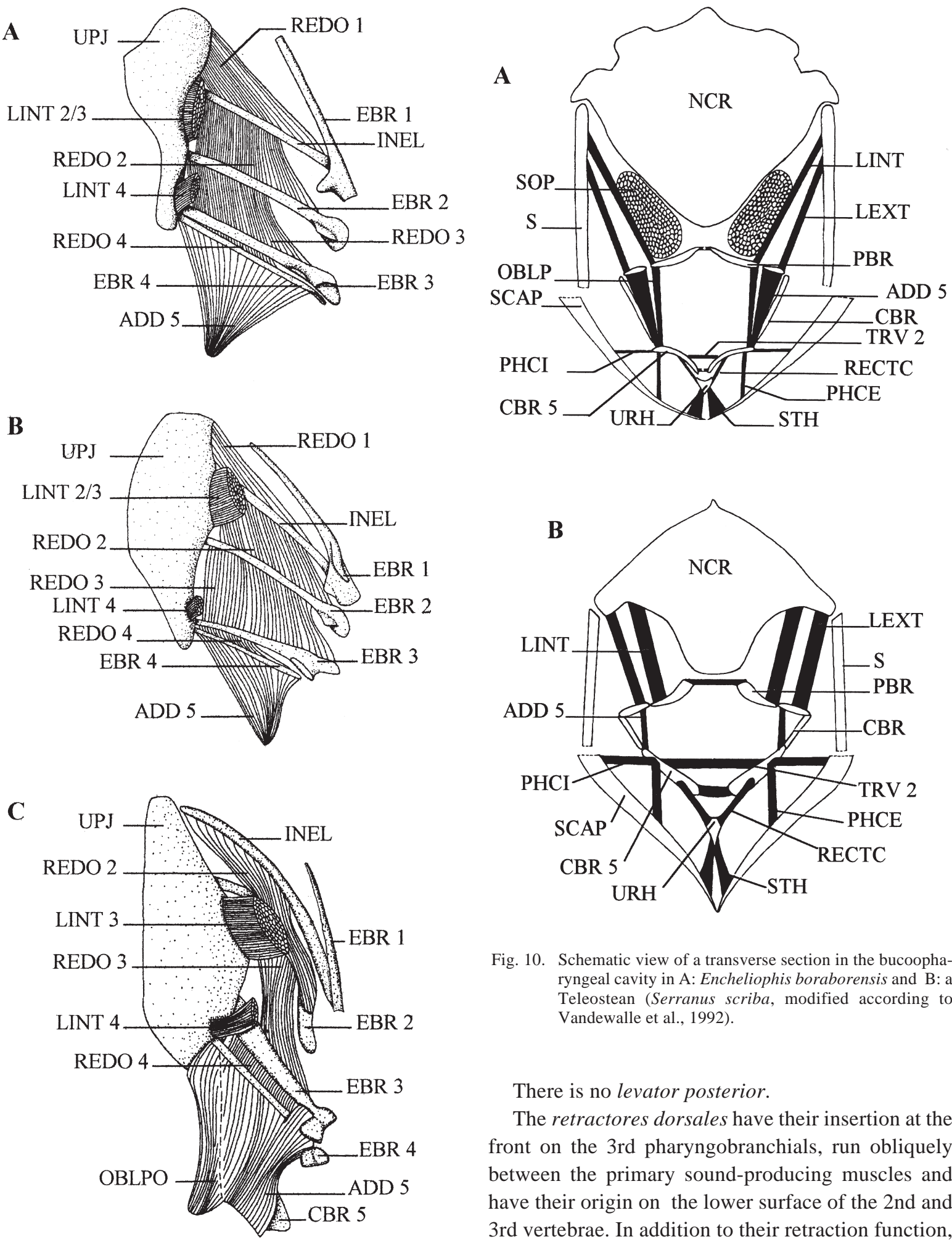

Fig. 10. Schematic view of a transverse section in the bucoopharyngeal cavity in A: Encheliophis boraborensis and B: a Teleostean (Serranus scriba, modified according to Vandewalle et al., 1992).

There is no levator posterior.

The retractores dorsales have their insertion at the front on the 3rd pharyngobranchials, run obliquely between the primary sound-producing muscles and have their origin on the lower surface of the 2 nd and $3 r d$ vertebrae. In addition to their retraction function, the disposition of these muscles enables them to lift the UPJ.

Fig. 9. Dorsal view of the half right branchial basket dorsal musculature when the transversus dorsalis and the obliquus dorsalis are removed in A: Encheliophis boraborensis, B: Encheliophis homei, C: Encheliophis gracilis.

E. gracilis has several features which differ from the other three species (Figs 7, 8, 9). The first relate to the insertion of some muscles (Table 1): (1) There is 
no 2nd/3rd levator internus, but only a 3rd levator internus on the 3rd pharyngobranchial and some of the fibres of the latter are attached to the prootic of the neurocranium. (2) The obliquus posterior is attached to the 4th epibranchial and not the 4th pharyngobranchial. (3) Some 5th adductor branchialis muscle fibres are attached to the 3rd epibranchial and the 4th epibranchial. There are also a few other differences: (1) At the front, the 1st rectus dorsalis is not totally covered by the transversus dorsalis anterior and the 1st obliquus dorsalis. (2) The transversus dorsalis centralis is partly covered by the transversus dorsalis anterior. (3) The obliquus dorsalis superficialis covers nearly all the transversus dorsalis posterior.

\section{DISCUSSION}

In Teleosteans in general, the first epibranchials are not only linked to the first pharyngobranchials but also articulate with the second, playing a role in particular in the support and the movements of the UPJ (Liem \& Greenwood, 1981; Lauder, 1983; Liem, 1986; Vandewalle et al., 1992). The situation is different in the four Carapidae species: on the one hand the 1st pharyngobranchials do not seem to be connected to the neurocranium and, therefore, may not be involved in the suspension of the UPJ, and on the other hand the 1st epibranchials are separate and are not jointed to the 2 nd pharyngobranchials. The interarcual element occupies the place of the first epibranchial and could ensure some of the functions of the latter. As is suggested by Rosen \& Parenti (1981), these interarcual elements could in fact be the isolated mesio-caudal branches of the 1st epibranchials. The presence of the primary sound-producing muscles (Figs. 5, 10) could be at the origin of this original disposition because they do not allow the 1st pharyngobranchials to become attached to the neurocranium in the normal way as is the case with most Teleosteans (Anker, 1978; Liem \& Greenwood, 1981; Lauder, 1983; Liem, 1986; Liem \& Sanderson, 1986; Vandewalle et al., 1992, 1995). Apparently, the primary sound-producing muscles cause a lateral displacement of the 1st pharyngobranchials and the 1st epibranchials, depriving these from a contact with the UPJ. In this situation, the suspension function of the front of the pharyngeal jaws on the neurocranium usually provided by the 1st pharyngobranchials is no longer possible. This loss of function could explain the reduc- tion of the 1st pharyngobranchials. In Ophidiidae and Bythididae, there is no independent interarcual element but the epibranchial is extended to the 2 nd pharyngobranchial by a cartilaginous posterior head. Its anterior head is attached to a bony 1st pharyngobranchial. In Ophidiidae and Bythididae, the soundproducing muscles are situated further back on the neurocranium. It therefore seems that the situation observed in Carapidae could be related to the more rostral position of the primary sound-producing muscles. Birdsong (1975), Rosen \& Parenti (1981) and Stiassny (1982) also report the presence of interarcual elements in certain Gobiidae, certain Cichlidae and many Atherinomorphs. But, in the latter, the interarcual element does not seem to relate to modifications regarding the anterior parts of the UPJ.

Generally speaking, as it is the case with many Teleosteans whose pharyngeal jaws have altered very little (Liem \& Greenwood, 1981; Lauder \& Liem, 1983; Vandewalle et al., 1992, 1995), the four species UPJ and LPJ function seems simply to transport the food. The main differences regarding the LPJ and UPJ in the four species concern the strength of the skeletal pieces and the teeth (Figs. 1, 3, 4). These differences could be related to the fish's diet. Indeed, the diet of E. boraborensis, E. homei and C. acus consists mainly of crustaceans and fishes (Arnold, 1953; Smith, 1964; Hipeau-Jacquotte, 1967; Trott, 1970; Van Den Spiegel \& Jangoux, 1989). The strength and closeness of their LPJ and the few, sharp teeth in their LPJ and UPJ may be in relation to a simple transport of rough preys. This assumption seems to be confirmed by the presence of entire prey in the stomach of E. boraborensis, C. acus and E. homei. Moreover, according to Vandewalle et al. (1995), a branchial system with thin sharp teeth is not very efficient for transporting soft elements. In E. gracilis, seen as a parasite feeding on the gonads, viscera and arborescent organs of Holothurians (Strasburg, 1961; Smith, 1964, Trott, 1970; Van Den Spiegel \& Jangoux, 1989), the ceratobranchials are thinner, more widely spaced and contain cardiform teeth organised in rows whereas the UPJ have more tapered teeth. A hypothesis is that the cardiform teeth organisation could constitute a sawing system used to cut up soft food. These stand in contrast to fine, sharp teeth that would be able to retain the cut food and transport it as seen in the other three species. In addition, according to Liem \& Greenwood (1981) and Vandewalle et al. (1994), the teeth on the third basi- 
branchial and/or the third hypobranchials in the latter species may constitute an argument for considering their bucco-pharyngean system as more primitive. The fact that the upper jaw teeth of the four species are directed caudally and medially would allow food to be concentrated in the entry of the oesophagus during the retraction movements of these pharyngeal pieces which probably do most of the transport, as in all Teleosteans possessing retractor dorsalis muscles (Liem \& Greenwood, 1981; Lauder \& Liem, 1983; Liem, 1986; Liem \& Sanderson, 1986 ; Galis, 1992).

The branchial musculature of Carapidae has many distinctive features. The first involves the upper insertions of the levatores externi and interni (Fig. 10). Generally, in teleosteans, all branchial basket levatores are found in the otic region of the neurocranium (Holstvoogd, 1965; Nelson, 1967, 1969; Lauder, 1983; Liem \& Sanderson, 1986; Claes \& De Vree, 1992; Vandewalle et al., 1995). In E. boraborensis, C. acus, E. homei and E. gracilis, the levatores exter$n i$ and interni are found on the inner upper side of the hyomandibular, except for a few 3rd levatores interni fibres in E. gracilis which are attached to the neurocranium. Only Le Danois (1964) reports that the 4th levator externus of certain Antennaire are located on the hyomandibular. Emery (1880) situated the levatores externi and interni insertions of $C$. acus on the neurocranium.

These remarkable insertion sites of the levatores are probably linked to the presence of the two primary sound-producing muscles. In fact, these muscles, which are missing in other Teleosteans, run between the branchial basket and the neurocranium and occupy the usual place of the levatores (Holstvoogd, 1965; Nelson, 1967, 1969; Liem, 1970; Vandewalle, 1972; Winterbottom, 1974; Anker, 1978; Lauder, 1983; Liem \& Sanderson, 1986; Claes \& De Vree, 1992; Vandewalle et al., 1995). This may have led to restrictions requiring a lateral displacement of the levatores. In order to verify this assumption, it would be interesting to know the insertion places of the levatores in Ophidiidae in which the primary sound-producing muscles are shorter and are located on the back of the neurocranium (Courtenay, 1971; Howes, 1992). The displacement of the levatores externi and interni insertions of the branchial basket will have functional consequences. Usually in Teleosteans, these muscles pull forward and upward (Winterbottom, 1974; Liem \& Greenwood, 1981; Lauder, 1983;
Liem \& Sanderson, 1986; Wainwright, 1989; Vandewalle et al., 1992). Their more lateral insertion should enable them to spread their upper jaws but the efficiency of their contraction could be reduced insofar as they are attached to a mobile element. Moreover, the suspension movements could influence those of the branchial basket to some extent.

According to Liem \& Greenwood (1981), Wainwright (1989), and Galis \& Drucker (1996), levator posterior muscles associated with great 4 th levatores externi in some Teleosteans are involved in the application of the UPJ against the LPJ and promote the crushing and the chewing of food. The missing levator posterior and the presence of the small 4 th levator externus therefore confirm the assumption that their pharyngeal jaws only transport food in E. boraborensis, C. acus, E. homei and E. gracilis. In E. gracilis, a great 5th adductor branchialis whose insertion covers the whole length of the 4th epibranchial, part of the 3rd epibranchial and a large obliquus posterior muscle compared with the three other species could be related to the work of cutting their soft food.

\section{CONCLUSIONS}

(1) The presence of primary sound-producing muscles has led to two major modifications of the branchial basket. (a) The 1st pharyngobranchials are not involved in the UPJ suspension and the 1st epibranchials are only indirectly related to the 2 nd pharyngobranchials by means of bony interarcual elements that are articulated between those two pieces. (b) The levatores externi and interni originate at the inner side of the hyomandibular, which is a very special feature among the teleosteans presently observed and which could have implications for the mobility of the branchial basket.

(2) The muscular and skeletal morphology of the branchial baskets seems at least partly related to the diet of the four species. In E. boraborensis, E. homei and $C$. acus, the strength of 5 th ceratobranchials (LPJ), which have changed but little and which contain sharp teeth, the lack of levator posterior, the thinness of the 4th levatores externi, the presence of the retractores dorsali on the one hand and the presence of entire prey in the stomach on the other hand argue in favour of pharyngeal movements which are only able to transport the food. In E. gracilis, less strong and more widely spread LPJ with cardiform teeth as 
opposed to the longer teeth of the UPJ and more developed 4th adductor branchialis and obliquus posterior could be related to cutting movements for soft prey in addition to the transport movements.

(3) Some morphological observations were justified either by the appearance of a "new" structure or by the originality of their functions. No reason has so far been found for many others. For example, there is no perceptible reason for the form of the teeth ending in a conical dome or the variations in the mutual overlapping of some branchial muscles.

(4) In addition, observations of the morphology of the branchial basket tend to group together E. boraborensis and E. homei with $C$. acus as opposed to $E$. gracilis, which is a case apart, and argue against the generic change suggested by Markle and Olney (1990).

\section{ACKNOWLEDGEMENTS}

The authors would like to thank C. Michel (Aquarium, Liège, Belgium), J.M. Ouin, G. Seghers (Laing Island Biological Station, Papua New Guinea), and D. Bay (S.T.A.R.E.S.O., Calvi, France) for helping to fish the Carapidae specimens, G. Goffinet and N. Decloux for the SCM photos study and Mrs. K. Bloomer for the linguistic assistance. This work is supported by grant $\mathrm{n}^{\circ} 1.4560 .96$. from the Belgian "Fonds National de la Recherche Scientifique".

\section{ABBREVIATIONS}

ADD 5: adductor branchialis 5;

BBR: basibranchial;

CBR 1 to 5: ceratobranchial 1-5;

EBR 1 to 5: epibranchial;

GR: gill rakers;

INEL: interarcual element;

HBR 1 to 3: hypobranchial 1 to 3;

LEXT 1 to 4: levator externus 1 to 4;

LINT 3 and 4: levator internus 3 and 4;

LINT 2/3: levator internus 2/3;

LPJ: lower pharyngeal jaws;

NCR: neurocranium;

OBLDO 1: obliquus dorsalis 1;

OBLDO 2: obliquus dorsalis 2;

OBLDO 3s: obliquus dorsalis 3 superficialis;

OBLDO3 p: obliquus 3 profondis;

OBLDO4: obliquus dorsalis 4;

OBLPO: obliquus posterior;

OBLV 1 to 3: obliquus ventralis 1 to 3 ;
PBR: pharyngobranchial;

PHCE: pharyngocleithralis externus;

PHCI: pharyngocleithral internus;

RD: retractor dorsalis;

RECTC: rectus communis;

RECTV: rectus ventralis;

REDO 1 to 4: rectus dorsalis 1 to 4;

S: suspensorium;

SB: swimbladder;

SCAP: pectoral girdle;

SOP: primary sound-producing muscle;

STH: sternohyoidus;

TRD 1: tranversus dorsalis anterior;

TRD 2: tranversus dorsalis centralis;

TRD 3: tranversus dorsalis posterior;

TRV 1: tranversus ventralis anterior ;

TRV 2: tranversus ventralis posterior;

UPJ: upper pharyngeal jaw;

URH: urohyal.

\section{REFERENCES}

Allis EPJ (1915): The homologies of the hyomandibula of the gnathostome fishes. Ibid 26: 563-624.

Anker GCH (1978): Analyses of respiration and feeding movements of the three-spined sticckleback, Gasterosteus aculeatus L. Neth J Zool 28: 485-523.

Arnold DC (1953): Observation on Carapus acus (Brünnich) (Jugulares, Carapidae). Publ Sta Zool Napoli 24: 152-166.

Ballard J (1991): The Pearlfish. Afr Wild 45: 16-19.

Birdsong RS (1975): The osteology of Microgobius signatus Poey (Pisces: Gobiidae), with comments of other gobiid fishes. Bull Flor St Mus Biol Sc 19: 135-186.

Bougis P, Ruivo M (1952): Recherches sur le poisson de profondeur Benthocometes robustus (Goode et Bean) (= Pteridium armatum, Doederlein) (Brotulidae). Trav $C L$ OEC Alg 17: 155-209.

Claes G, De Vree F (1992): Pharyngeal muscle activities dring food food processing in Oreochromis niloticus (Pisces: Cichlidae). Zool Jarb Anat 122: 173-178.

Courtenay WR (1971): Sexual dimorphism of the sound producing mechanism of the striper cusk-eel, Rissola marginata (pisces: Ophiidae). Copeia 1971: 259-268.

Courtenay WR, McKittrick FA (1970): Sound-producing mechanisms in carapid fishes, with notes on phylogenetic implications. Mar Biol 7: 131-137.

Demski LS, Gerald JW, Popper AN (1973): Central and peripheal mechanisms of teleost sound production. Am Zool 13: 1141-1167.

Emery DC (1880): Contribuzioni all' Ittiologia: III. Aggiunte alla Sinonimia e alla Storia naturale dei Fierasfer. Mitt Zool Sta Neapol 3: 281-283.

Galis F (1992): A model biting in the pharyngeal jaws of a 
cichlid fish: Haplochromis piceatus. J theor Biol 155: 343-368.

Galis F, Drucker EG (1996): Pharyngeal biting mechanics in centrarchid and cichlid fishes: insight into a key evolutianory innovation. J Evol Biol 9: 641-670.

Govoni JJ, Olney JE, Markle DF, Curtsinger WR (1984): Observations on structure and evaluation of possible functions of the vexillum in larval Carapidae (Ophidiiformes). Bull Mar Sc 34(1): 60-70

Gustato G (1976): Osservazioni sulla biologica e sul comportamento di Carapus acus (Ophioidei, Percomorphi). Boll Soc Natur Napoli 85: 505-535

Hipeau-Jacquotte R (1967): Notes de faunistique et biologie marines de Madagascar.IV. Observation sur le comportement $\mathrm{du}$ poisson Carapidae: Carapus homei (Richardson, 1844) de Madagascar. Rec Trav Sta Mar Endoune 6: 141-151

Holstvoogd C (1965): The pharyngeal bones and muscles in Teleostei, a taxonomic study. Koninkl Nederl Akad Weten Ser C 68(3): 209-218

Howes GJ (1992): Notes on the anatomy and classification of ophidiiforme fishes with particular reference to the abyssal genus Acanthonus Günther, 1878. Bull Br Mus (Nat Hist) Zool 58(2): 95-131.

Le Danois Y (1964): Etude anatomique et systématique des Antennaires de l'ordre des Pédiculates. Mém Mus Nat Hist Nat 31: 1-162.

Lauder GV (1983): Functional design and evolution of the pharyngeal jaw apparatus in euteleostean fishes. Zool $\mathrm{J}$ Lin Soc 77: 1-38.

Lauder GV, Liem KF (1983): The evolution and interrelationships of the Actinopterygian fishes. Bull Mus Comp Zool 150: 95-197.

Liem KF (1986): The pharyngeal jaw apparatus of the Embitocidae (Teleostei): a functional and evolutionary perspective. Copeia 1986: 311-323.

Liem KF, Greenwood PH (1981): A functional approach to the phylogeny of the pharyngognath Teleosts. Am Zool 21: 83-101.

Liem KF, Sanderson SL (1986): The pharyngeal jaw apparatus of labrid fishes: a functional morphological perspective. J Morphol 187: 143-158.

Markle DF, Olney JE (1990): Systematics of the Pearlfish (Pisces: Carapidae). Bull Mar Sci 47: 269-410.

Meyer-Rochow, VM (1977): Comparison between 15 Carapus mourlani in a single Holoturian and 19 carapus mourlani from starfish. Copeia 1977: 582-585.

Nelson GN (1967): Branchial muscles in some generalized telostean fishes. Acta Zool 48: 277-288.

Nelson GJ (1969): Gill arches and the phylogeny of fishes, with notes on the classification of vertebrates. Bull Am Mus Nat Hist 141: 477-552.

Rosen DE, Parenti LR (1981): Relationships of Oryzon and the groups of Atherinomorph fishes. Am Mus Nov 2719: $1-2$.
Smith CL (1964 ): Some Pearlfishes from Guam, with notes on their ecology. Pac Sci 18: 34-40.

Smith CL, Tyler JC, Feinberg MN (1981): Population ecology and biology of the pearlfish (Carapus bermudensis) in the lagoon at Bimini, Bahamas. Bull Mar Sci 3: 876902

Stiassny, MJL (1982): The relationships of the neotropical genus Cichla (Perciformes, Cichlidae): a phyletic analysis including some functional considerations. J Zool London 197: 427-453.

Strasburg DW (1961): Larval carapid fishes from Hawaii, with remarks on the ecology of adults. Copeia 1961: 478-480.

Tavolga WN (1962): Mechanisms of sound production in the ariid catfishes Galeichthys and Bagreus. Am Mus Nat Hist 124: 5-30.

Taylor WR, Van Dijk GC (1985): Revised procedure for staining and clearing small fishes and other vertebrates for bone and cartilage study. Cybium 2: 107-119.

Trott LB (1970): Contribution of the biology of carapid fishes (Paracanthopterygian: Gadiformes). Univ Calif Publ Zool 89: 1-41.

Van Den Spiegel D, Jangoux M (1989): La symbiose entre poissons Carapidae et Holoturies autour de l'île de Laing ( Mer de Bismarck, Papouasie Nouvelle Guinée). Indo-Mal Zool 6: 223-228.

Vandewalle P, Havard M, Claes G, De Vree F (1992): Mouvements des machoires pharyngiennes pendant la prise de nourriture chez le Serranus scriba (Linne, 1758) (Pisces, Serranidae). Can J Zool 70: 145-160.

Vandewalle P, Huyssene A, Aerts P, Verraes W (1994): The pharyngeal apparatus in teleost feeding. In : Bels VL, Chardon M, Vandewalle P, eds., Biomechanics of Feeding in Vertebrates, Berlin, Springer.

Vandewalle P, Saintin P, Chardon, M (1995): Structures and movements of the buccal and pharyngeal jaws in relation to feeding in Diplodus sargus. J Fish Biol 46: 623-656.

Wainwright PC (1989): Functional morphology of the pharyngeal jaw apparatus in perciform fishes: an experimental analysis of the Haemulidae. J Morph 200: 231245.

Winn HE, Marshall JA (1963): Sound-producing organ of the squirrelfish, Holocentrus rufus. Physiol Zoöl 36(1): 34-44.

Winterbottom R (1974): A descriptive synonymy of the striated muscles of the Teleostei. Proc Acad Nat Sc Philad 125(12): 225-317.

Received: September 1997

Accepted after revision: April 1, 1998 